Editorial

\title{
Marking the First Year of KRITIKE: An Online Journal of Philosophy
}

The Editor

$\mathrm{W}$ e are proud to mark the first year of KRITIKE: An Online Journal of Philosophy. Our journey has, so far, been both uplifting and humbling. In the course of one year, we have learned the value of taking careful steps, yet ones which yield well-founded results. The articles included in this issue emerge from our careful selection of submissions with varying topics, ranging from the more popular philosophical themes such as tragedy, love, religion, death, and human existence; to social and political reflections on hospitality, war, mass mentality, and fascism; down to more specialized discussions about the exclusion principle, visual theory, and Kant's third antinomy. We are also pleased to offer you the journal's first three book reviews.

First off is an essay that invites us to visit the Derridian abode. In "Interruptions: Derrida and Hospitality," Mark. W. Westmoreland gestures towards a rethinking of the notion of "hospitality" through the lenses of Jacques Derrida. This gesture presupposes the need to revaluate our understanding of philosophy and how this understanding shapes our reflections on the themes of iterability, promise, democracy, fraternity, and forgiveness. As opposed to the conventional practice of hospitality-one which is based on conditions of rights, duties, and obligations-Westmoreland echoes Derrida's deconstructive, non-juridical, and quasi-Levinasian approach to the hidden logic of hospitality, that is to say, hospitality as an "interruption of the self." Derrida's notion of hospitality, for Westmoreland, borders on an overcoming of the aporia between the self and the other. Meanwhile, Kenneth Masong offers us a "tragic" reading of Iris Murdoch's The Bell. Masong attempts to show that Murdoch is critical of the reduction of moral philosophy to prescriptive ethics, a form of ethical life that breeds what Charles Taylor calls "the punctual self" - a free and independent self, "yet, cultureless, ahistorical and dreadfully solitary." According to Masong, Murdoch bids to salvage the Platonic elements of moral philosophy and metaphysics by a redescription of the vision of the Good that dissolves the vision of God in religious thought. Tragedy as a literary genre and philosophical concept is critiqued and placed within the complexities of moral metaphysics; tragedy, therefore, operates as an existential corrective apparatus that disturbs the enclosure of love in convention and neurosis. 


\section{ii MARKING THE FIRST YEAR OF KRITIKE}

Saitya Brata Das' essay "To Philosophize is to Learn How to Die?" is an ambitious and thought-provoking inquiry into the nature of human finitude as well as the finitude of philosophy. The Heideggerian influence upon Das' reflections is undeniable; this is seen in the author's adaptation of a "Heideggerian tone" that goes beyond the ordinary academic prose style of writing. Das argues that an overcoming of traditional metaphysics should be intimately tied to the question of death, whether in the Hegelian sense as negativity or Heideggerian sense as nothingness. The question of finitude becomes central to philosophy because, as Das puts it, "Philosophical thinking, as it is thinking of existence, is essentially finite thinking." Hence, philosophy is tied to the human, to the limitations of being human, and this is not an accidental relationship. The melancholic apothegm "to philosophize is to learn how to die" - could very well have been Greek in origin, but is also attributed to the French author Michel de Montaigne-is used by Das to illustrate that philosophical mastery entails the mastery of the art of dying. The essay reads Heidegger, Rosenzweig, and Nietzsche to evince the tragic-heroic pathos that permeates in their writings; Das goes beyond the tragic-heroic pathos by redefining finitude as "the very unconditional condition of human existence." To some extent F. P. A. Demeterio's comparative analysis of the works of the French philosopher Albert Camus and the Filipino novelist F. Sionil Jose is also an inquiry into the nature of human finitude. Demeterio observes that Camusian themes of absurdity, alienation, disillusionment, and a somewhat pessimistic view of religious faith and brotherhood are "cognitively remote for a contemporary Filipino reader." Demeterio goes around this disparity by aligning some of Jose's works with that of Camus' through what is referred to in the article as the Heideggerian hermeneutic approach. The result is a dialogical interplay between Jose and Camus that highlights the thematic affinities between their works as well as some tensions. According to Demeterio, Camus champions the absurd modern man the "lonely individual, without a past, nor future, nor meaningful love life, nor children," while Jose presents an image of the modern Filipino that, in some way, contrasts that of Camus' absurd man.

The fifth essay of this issue "The War on Concepts: The Thought of Jan Patočka and the War on Terror" by Katy Scrogin tackles the current issue of the Iraq war. The paper is a critical assessment of the Bush administration's war rhetoric, and this is done by employing the Czech philosopher Jan Patočka's distinctions between "light" and "dark" and between "peace" and "war." Scrogin vehemently asserts that the Bush administration is not only waging a war against concrete enemies, but is also waging a war against the abstract concept of "terrorism." By banking on a reified concept of terrorism, Bush and his allies are able to justify and prolong military presence in the Middle East, as well as in other parts of the world. Scrogin's paper invites us to look at Bush's twisted war rhetoric critically; she suggest that we consider Patočka's notion of "the solidarity of the shaken" as a point of departure from which a struggle against a one-sided rhetoric of war could ensue. Another contemporary socio-politico phenomenon that requires our attention is "mass 
mentality." Saladdin Said Ahmed explores the relationship between mass mentality and its current form, the "culture industry." Ahmed launches a fervent criticism of fascism which he argues can only exist through the collective psychology of mass individuals. Ahmed's arguments are informed by his reading of some of Theodor Adorno's own engagement with the themes off mass mentality, culture industry, and fascism. Dialectic of Enlightenment, The Culture Industry, and The Authoritarian Personality are, therefore, central in Ahmed's essay which seems to argue that in the current state of culture today, a culture replete with consumerism ad nauseam, fascism, albeit in a subtle way, becomes a normative element of society.

Wilson Cooper's "The Causal Relevance and Heterogeneity of Program Explanations in the Face of Explanatory Exclusion" discusses the tension between two opposing claims regarding causal explanations. Cooper juxtaposes Jaegwon Kim's principle of explanatory exclusion to that of Frank Jackson's and Philip Pettit's claim that properties can be causally relevant without being causally efficacious. The paper, towards the end, shows that this tension is only apparent, as both program explanations and explanatory exclusion principle can coexist quite comfortably. Meanwhile, Todd D. Janke, for his part, draws from G. H. von Wright and Frederick Stoutland, contemporary philosophers of action, to defend Kant's resolution of the third antinomy. Janke maintains that Kant's resolution to the third antinomy (between causal laws and free agency) prefigured subsequent debates in contemporary philosophy of action. What Janke takes to be "ambiguities in Kant's persuasive account of the reconcilability of mechanistic determinism and human freedom" are clarified through von Wright and Stoutland, thereby challenging Norman Kemp Smith's criticism of the third antinomy. The overall purpose of the paper "is to show that there is in Kant's resolution of the third antinomy a much more cogent and persuasive philosophical position on agency than is often recognized."

Michael James Braund closes the article section with his essay "The Structures of Perception: An Ecological Perspective." He tackles the debate about visual perception that emerges between ecological psychology and the classical approach of Cartesianism. As opposed to Descartes' view of perception based on a dualism of mind and body, Braund argues with James J. Gibson that perceptual awareness of reality is not merely due to representations formed in our minds; rather perception is a product of an "embodied" mind. Braund defends Gibson's brand of empiricism and maintains that the environment contains all of the information needed to specify its properties. Moreover, Braund analyses the concept of "structure" that locates the moving, perceiving body at the heart of meaningful perceptual experience; an experience which emerges in the dynamical structures that cross the body and the world.

In the second section we feature KRITIKE's first set of book reviews. First of which is Marko Zlomislic's review of Jason Powell's Jacques Derrida: A Biography (2006), which is perhaps the very first biography of the Father of deconstructionism after his death in 2004. Zlomislic gives a penetrating review 


\section{iv MARKING THE FIRST YEAR OF KRITIKE}

of Powell's book, where he welcomes the author's achievement but points out several weak points of the book. According to Robert C. Cheeks, C. Stephen Evans's Kierkegaard: On Faith and the Self, Collected Essays (2006) broadly and deeply explores the philosophy and theology of the Danish philosopher Soren Kierkegaard. Cheeks comprehensively comments on the sections of the book giving us readers a foreground treatment of the important aspects of Kierkegaard's thought. Finally, Marella Ada Mancenido reads Sartre (2005) by David Drake alongside Robert Bernasconi's How to Read Sartre (2006). Mancenido attempts to demonstrate "how beginners in Sartre's philosophy could complimentarily read these two books as well as critically engage with their authors."

I would like to express my deepest gratitude to the people who lent their time and effort, despite their busy schedules, in the preparation of this third issue: to a number of colleagues from the Department of Philosophy of Macquarie University, Sydney, namely, Robert Sinnerbrink, Mark Kelly, Lise Marie Andersen, and Melanie Rosen; to Br. Romy Abulad of San Carlos University, Cebu; to Kristina Lebedeva of DePaul University, USA; to Xiaofei Tu of West Virginia University, USA; to Jonas Christensen of the University of Edinburgh, UK; and to Brian Lightbody of Brock University, Canada. I would also like to thank the officers of the Philosophical Association of the Philippines, especially Rowena Azada-Palacios of Ateneo de Manila University, for including our call for papers in the recent PAP newsletter. 